Tinjauan Pustaka

\title{
Biomarker Acute Kidney Injury (AKI) pada Sepsis
}

\author{
Dional Setiawan¹, Harnavi Harun², Syaiful Azmi², Drajad Priyono²
}

\begin{abstract}
Abstrak
Sepsis didefinisikan sebagai infeksi bersama dengan manifestasi sistemik dari infeksi. Sepsis berat adalah penyebab $50 \%$ kasus acute kidney injury (AKI) pada pasien kritis. Patofisiologi cedera ginjal akut (AKI) pada sepsis disebabkan oleh respon inflamasi, toksin dan perubahan hemodinamik glomerulus. Tingkat keparahan disfungsi ginjal tergantung pada tingkat keparahan sepsis. Perubahan laju filtrasi glomerulus (GFR) adalah fenomena AKI yang terlambat. Diagnosis AKI dengan mengukur kreatinin serum. Sayangnya, kreatinin adalah indikator yang kurang dapat diandalkan selama perubahan akut pada fungsi ginjal. Munculnya penanda biologis baru dalam lingkup AKI sangat membantu bagi dokter untuk dapat mendiagnosa awal AKI. Penanda biologis AKI bisa menjadi komponen serum atau urin. Penanda biologis urin menjanjikan untuk mendeteksi awal AKI, sehingga dapat berguna untuk diagnosis dini.
\end{abstract}

Kata kunci: acute kidney injury, sepsis, biomarker

\begin{abstract}
Sepsis is defined as infection along with systemic manifestations of infection. Severe sepsis is the cause of $50 \%$ of acute kidney injury (AKI) cases in critical patients. Pathophysiology of acute kidney injury (AKI) in sepsis is caused by inflammatory response, toxin and changes in glomerular hemodynamics. The severity of renal dysfunction depends on the severity of sepsis. Changes in glomerular filtration rate (GFR) are a late phenomenon of AKI. Diagnosis of $A K I$ by measuring serum creatinine. Unfortunately, creatinine is a less reliable indicator during acute changes in kidney function. The emergence of new biological markers within the scope of AKI is very helpful for clinicians to be able to diagnose early AKI. Biological markers of AKI can be a component of serum or urine. Urine biological markers are promising to detect early AKI, so it can be useful for early diagnosis.
\end{abstract}

Keywords:acute kidney injury, sepsis, biomarker

Affiliasi penulis: 1.Program Studi Pendidikan Profesi Dokter Spesialis-1 IImu Penyakit Dalam FK Unand/RSUP M Djamil Padang, 2. Subbagian Ginjal Hipertensi Bagian IImu Penyakit Dalam FK Unand/RSUP M Djamil Padang,

Korespondensi :dionalsetiawan@gmail.com Telp: +6285274018375

Pendahuluan

Sepsis didefinisikan oleh Surviving Sepsis

Campaign Guideline 2012 (SSCG 2012) sebagai adanya infeksi bersamaan dengan manifestasi sistemik dari infeksi. Sepsis terjadi sekitar 750.000 kasus setiap tahun di Amerika Serikat, meningkat dari $2,1 \%$ menjadi $4,3 \%$ pada pasien rawat inap, dan $11 \%$ dari seluruh perawatan di ICU (Intensive Care Unit). Dari tahun 1979 sampai tahun 2000, kasus sepsis meningkat setiap tahunnya sekitar 8,7\%, dari 164.000 kasus (82,7 kasus per 100.000 penduduk) menjadi hampir 660.000 kasus $(240,4$ kasus per 100.000 penduduk). Sepsis menyebabkan angka kematian yang tinggi, dengan mortalitas $22-76 \%$ pada sepsis berat. Sepsis merupakan penyebab kematian ketiga dari 10 penyebab kematian terbanyak di Amerika Serikat, setelah penyakit jantung dan neoplasma ganas. Kejadian sepsis meningkat sesuai dengan bertambahnya usia, kondisi ini menunjukkan bahwa jumlah kasus akan meningkat di masa mendatang..$^{1,2}$

Sepsis berat adalah pemicu terjadinya $50 \%$ kasus acute kidney injury (AKI) pada pasien kritis. Beberapa laporan dunia menunjukkan insiden AKI yang bervariasi antara 0,5-0,9\% pada komunitas, 0,7$18 \%$ pada pasien yang dirawat di rumah sakit, $20 \%$ pada pasien yang dirawat di ICU, dengan angka kematian yang dilaporkan berkisar $25-80 \%$. Oleh karena itu sepsis dan AKI akan sering diobservasi pada pasien dengan penyakit kritis di ICU. Selain itu, sepsis dan AKI secara sinergis meningkatkan mortalitas pada pasien ICU. 3,4

Meskipun pada pasien dengan infeksi yang tidak terlalu parah, insiden AKI tetap terjadi sebanyak $16 \%-25 \%$. AKI akibat sepsis memiliki hubungan dengan angka mortalitas 50\%-60\% tergantung tingkat keparahannya. AKI akibat sepsis ditandai dengan penurunan kemampuan filtrasi dan eliminasi hasil metabolisme nitrogen yang terjadi secara progresif, biasanya terjadi selama beberapa jam sampai beberapa hari setelah onset sepsis. $3,4,5,6$ 
Klasifikasi AKI yang terbaru menyatakan bahwa perubahan sedikit saja pada kreatinin serum dikaitkan dengan hasil luaran pasien yang lebih buruk. Hal ini, bagaimanapun, tetap merupakan kriteria fungsional untuk $\mathrm{AKI}$ dan menyiratkan bahwa perubahan LFG mungkin merupakan fenomena yang terlambat dari sindrom AKI. Dalam praktek klinis saat ini, AKI biasanya didiagnosis dengan mengukur kreatinin serum. Sayangnya, kreatinin merupakan indikator yang kurang dapat diandalkan selama perubahan akut pada fungsi ginjal. Kenaikan kreatinin serum merupakan tanda dari perubahan filtrasi glomerulus yang telah berlangsung selama berjamjam atau hari. $7,8,9$

Kreatinin serum memiliki banyak keterbatasan dalam mendiagnosa $\mathrm{AKI}$, terutama dalam ruang lingkup unit perawatan intensif sehingga kurang sensitif untuk menggambarkan tingkat disfungsi ginjal pada pasien sakit kritis. Munculnya penanda biologis baru dalam lingkup AKI sangat membantu para klinisi untuk dapat mendiagnosa AKI dengan sensitivitas dan spesifisitas yang tinggi. Kurangnya biomarker awal AKI pada manusia hingga saat ini telah mengurangi kemampuan kita untuk memulai terapi yang potensial efektif pada waktu yang tepat. Memang, penyelidikan manusia kini telah jelas menetapkan bahwa intervensi lebih awal meningkatkan kemungkinan perbaikan disfungsi ginjal. ${ }^{10}$

\section{Patofisiologi Acute Kidney Injury (AKI) pada Sepsis}

Respon sistem imun bawaan terhadap infeksi memicu mekanisme adaptif yang dapat mempengaruhi tubulus ginjal, fungsi vaskuler dan glomerulus. Patogen melepaskan berbagai macam molekul, seperti lipopolisakarida, asam lipoteikoat, atau DNA, yang dikenal sebagai pathogen-associated mollecular pattern (PAMP) ke dalam sirkulasi. Selain itu, cedera dan gangguan pada sel membuat sel mengeluarkan kandungan intraseluler yang dinamai damage associated mollecular pattern (DAMP). PAMPs dan DAMPs dikenal oleh sel sel tubuh kita yang dapat dapat berikatan dengan reseptor, seperti Toll like receptor (TLR) yang ada pada sel-sel imun. Sebagai respon terhadap aktivasi ini, sel-sel imun mengeluarkan sitokin, kemokin dan reactive oxygen species (ROS) dan reactive nitrogen species (RNS). Pelepasan ROS dan RNS mengakibatkan kerusakan sel lebih banyak secara langsung melalui degradasi oksidatif pada lipid intraselular, protein dan DNA.8,9

Oleh karena ginjal menerima sebagian besar curah jantung dan menyaring volume plasma dalam jumlah banyak setiap jam, sehingga tubulus pada pasien sepsis terpapar dengan DAMPs, PAMPs, ROS dan RNS secara terus menerus. Kondisi ini mengancam kerusakan nefron atau stres pada tingkat seluler. ${ }^{8,9}$

Mekanisme sitoprotektif meliputi kemampuan untuk mengurangi kebutuhan energi dan pengunaannya, membatasi pembentukan ROS, menghilangkan organel disfungsional, dan mengatur kematian sel. Sel tubulus yang mengalami stress dapat menghentikan siklus sel/cell-cycle arrest, yang dapat menghentikan pembelahan sel normal dan menghemat energi sampai stimulus yang merugikan berkurang. 8,9
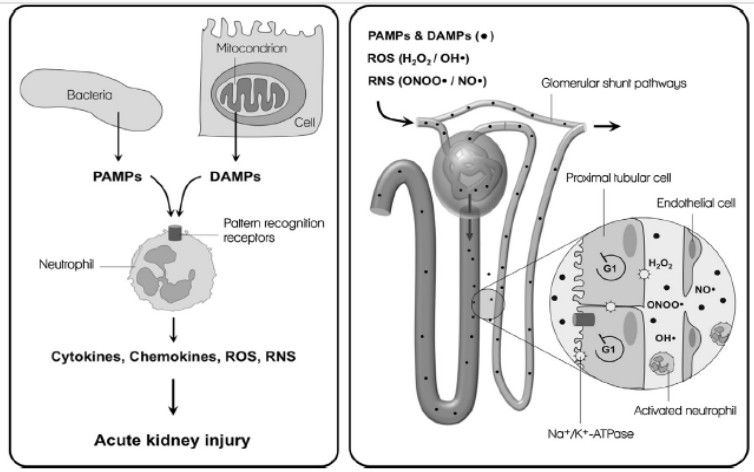

Gambar 1. Respon Ginjal Terhadap Sepsis. ${ }^{8}$

Penurunan glomerular filtration rate (GFR) merupakan hal penting yang terjadi pada AKI akibat sepsis. Glomerular filtration rate (GFR) yang rendah dianggap sebagai mekanisme protektif terhadap kerusakan lebih lanjut. Penurunan GFR berarti berkurangnya filtrasi terhadap DAMPs dan PAMPs, yang kemudian membatasi paparan toksin dan stres pada sel sel tubulus. Penurunan GFR juga berarti penurunan konsumsi energi karena terjadi penurunan jumlah sodium chloride yang terfiltrasi dan yang butuh direabsorpsi. 8,9

\section{Biomarker Acute Kidney Injury (AKI) pada} Sepsis

Penanda biologis AKI dapat merupakan komponen dari serum atau urin. Penanda biologis 
urine cukup menjanjikan untuk mendeteksi AKI awal, maka dapat diperkirakan lebih awal, karena itu, bisa berguna untuk diagnosis dini, identifikasi gangguan mekanisme, dan penentuan lokasi dan keparahan disfungsi. Istilah penanda biologis pertama kali dijelaskan pada tahun 1989, yang berarti indikator terukur untuk kondisi biologis tertentu dan untuk proses penyakit tertentu. Selain itu, badan pengawasan obat dan makanan amerika serikat/food and drug administrator (FDA) menggunakan istilah penanda biologi suntuk menggambarkan setiap indikator diagnostik yang dapat diukur dan digunakan untuk menilai risiko atau penyakit. Penanda biologis yang ideal untuk AKI harus terjangkau, cepat dan mudah untuk mengukur, tepat dan akurat, dan dapat menentukan tingkat keparahan disfungsi, khusus untuk ginjal, meningkat ditahap awal disfungsi, dengan sensitivitas dan spesifisitas yang tinggi. ${ }^{10}$

Dari sekian banyak penanda biologis baru yang tersedia, terdapat 4 penanda biologis yang saat ini secara luas digunakan para klinisi di seluruh dunia untuk mendeteksi AKI, antara lain Neutrophil Gelatinase-Associated Lipocalin (NGAL), cystatin C, KIM-1 dan interleukin-18. Kadar NGAL urin meningkat dalam waktu 2 jam setelah terjadinya disfungsi ginjal, sedangkan IL-18 dalam waktu 12 jam. ${ }^{10}$

\section{a) Kidney Injury Molecule-1}

Kidney Injury Molecule-1 atau KIM-1 adalah glikoprotein membran sel tipe 1 yang berisi 6-sistein menyerupai imunoglobulin. KIM-1 mRNA meningkat lebih tinggi dari gen lain menyusul disfungsi ginjal. Ekspresi gen tersebut meningkat dalam 24-48 jam setelah kejadian iskemik pada tikus. KIM-1 gen dan ekspresi protein yang tidak terdeteksi di ginjal normal. Fungsi KIM-1 pada ginjal adalah untuk membuat sel epitel mengenali dan memfagosit sel-sel mati di ginjal karena iskemia dan menyebabkan obstruksi lumen yang menyebabkan AKI. Dengan demikian, sel epitel dengan KIM-1 bekerja sebagai fagosit semi profesional. KIM-1 sangat spesifik dan sensitif dalam mengidentifikasi zat beracun ditubulus proksimal. Dari spesimen biopsi ginjal pada 6 pasien dengan akut tubular, kadar urin KIM-1 meningkat dalam 12 jam setelah disfungsi ginjal, mendahului pembentukan silinder. ${ }^{10}$
Dalam sebuah penelitian kecil cross-sectional pada manusia, KIM-1 ditemukan secara nyata diinduksi dalam tubulus proksimal di biopsi ginjal dari pasien dengan AKI (terutama iskemik), dan KIM-1 urin membedakan $\mathrm{AKI}$ iskemik dari pra-renal azotemia dan penyakit ginjal kronis. Pasien dengan AKI yang disebabkan oleh kontras tidak mengalami peningkatan urin $\mathrm{KIM}-1.10$

\section{b) Interleukin-18}

Interleukin (IL)-18 adalah sitokin pro inflamasi yang diinduksi ditubulus proksimal, dan kemudian dengan mudah dideteksi dalam urin setelah AKI iskemik pada hewan model. Dalam sebuah studicrosssectional, kadar urin IL-18 dengan nyata meningkat pada pasien dengan $\mathrm{AKI}$, tetapi tidak pada subyek dengan infeksi saluran kemih, penyakit ginjal kronis, sindrom nefritik, atau gagal ginjal pra renal. Studi pada manusia menunjukkan bahwa konsentrasi IL-18 meningkat dalam 24-48 jam sebelum AKI berdasarkan kriteria RIFLE. ${ }^{10}$

\section{c) Cystatin C}

Cystatin $\mathrm{C}$ adalah anggota dari super famili cystatin sistein protease inhibitor dengan berat molekul rendah 13,3 kDa yang disintesis oleh semua sel berinti pada tingkatproduksiyang konstan. Cystatin Csecara bebas disaring di glomerulusdan tidak direabsorpsi serta dikatabolisme oleh sel epitel tubulus, sehingga hanya dalam jumlah yang sangat kecil dapat dijumpai dalam urin. Kadar cystatin $\mathrm{C}$ serum tidak dipengarui oleh massa otot, diet, umur dan gender seperti halnya yang terjadi pada kreatinin. Ada beberapa hal yang dapat mempengaruhi nilai pengukuran cystatin $\mathrm{C}$ yaitu pasien dalam terapi kortikosteroid dan pasien dengan penyakit tiroid. Nilai cystatin $\mathrm{C}$ dilaporkan akan menurun pada pasien dengan hipotiroidisme dan meningkat pada hipertiroidisme. Nilai cystatin $\mathrm{C}$ juga akan meningkat pada pasien yang di terapi dengan kortikosteroid. ${ }^{10}$

Banyak studi menunjukkan cystatin C menjadi prediktor laju filtrasi glomerulus yang lebih baik dibandingkan kreatinin. Beberapa penelitian yang dilakukan menunjukkan bahwa cystatin $C$ serum mendiagnosa AKI lebih cepat dan lebih baik daripada kreatinin serum. ${ }^{10}$ 


\section{d) Neutrophil Gelatinase Associated Lipocalin}

Neutrophil Gelatinase-Associated Lipocalin

(NGAL) manusia diidentifikasi sebagai protein $25-\mathrm{kDa}$ gelatinase yang terikat secara kovalen dari neutrofil. NGAL biasanya dihasilkan pada tingkat yang sangat rendah dalam jaringan manusia, termasuk ginjal, paruparu, lambung, dan usus besar. Sintesis NGAL secara nyata diinduksi dalam epitel yang cedera. Sebagai contoh, konsentrasi NGAL akan meningkat dalam serum pasien dengan infeksi bakteri akut, dahak dari subyek dengan asma atau penyakit paru obstruktif kronik, dan cairan bronkial dari paru-paru emphysematous. ${ }^{10}$

Dalam sebuah studi cross-sectional, manusia dewasa di unit perawatan intensif dengan cedera ginjal akut sekunder yang disebabkan sepsis, iskemia, atau nephrotoksin menghasilkan peningkatan yang lebih besar dari 10 kali lipat dalam plasma NGAL dan lebih dari peningkatan 100 kali lipat dalam NGAL urin melalui Western blotting bila dibandingkan dengan kontrol normal. Kadar NGAL dalam urin dan serum berkorelasi dengan kadar kreatinin serum dan peningkatan kadar NGAL mendahului peningkatan kadar kreatinin serum. NGAL plasma disaring di glomerulus, dan mengalami reabsorpsi oleh tubular proksimal, karena itu, ekskresi NGAL dalam urin hanya terjadi ketika ada kerusakan tubular proksimal yang mengganggu reabsorpsi NGAL atau meningkatnya sintesis NGAL. ${ }^{10}$

Hasil penelitian Hidayat dkk (2012) didapatkan kadar NGAL urine penderita sepsis dengan AKI lebih tinggi secara bermakna dibandingkan dengan penderita sepsis tanpa AKI (3.380 ng/mL berbanding $116 \mathrm{ng} / \mathrm{mL} ; \mathrm{p}<0,001$ ). Pada cut-off point $107 \mathrm{ng} / \mathrm{mL}$, NGAL urine memiliki sensitivitas $100 \%$, spesifisitas $36 \%$, positive predictive value (PPV) 60,9\%, negative predictive value (NPV) $100 \%$, dan akurasi $68 \%$. Simpulan, kadar NGAL urine memiliki validitas yang baik dan dapat dijadikan sebagai penanda diagnosis terjadinya AKI pada penderita sepsis. ${ }^{11}$

\section{e) Cell-Cycle Arrest Biomarkers}

Penelitian internasional multisentrum melaporkan penemuan dan validasi dari dua $\mathrm{G}_{1}$ cellcycle arrest biomarkers (CCABs); tissue inhibitor of metalloproteinases (TIMP-2) dan insulin-like growth factor binding protein (IGFBP-7). Jika digabungkan, CCABs ini mendeteksi AKI dengan tingkat akurasi yang tinggi dan sangat bagus dalam mengidentifikasi pasien yang memiliki risiko akan segera mengalami AKI yang berat. ${ }^{12}$

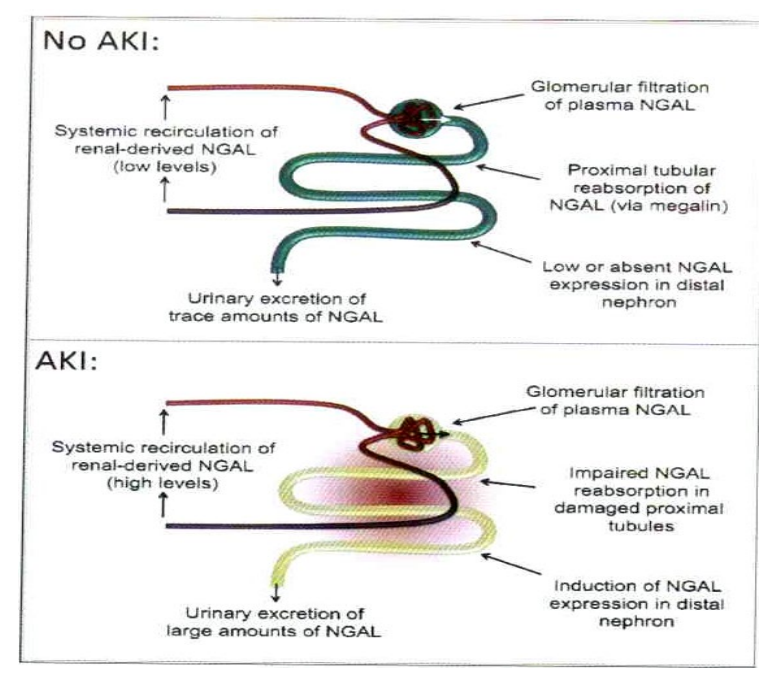

Gambar 2. Perjalanan NGAL pada AKI. ${ }^{11}$

Dua penelitian lain telah memperkirakan nilai prediktif dari [TIMP-2]-[IGFBP7], satu penelitian multisentrum di ICU secara umum dan satu penelitian di satu pusat tentang $\mathrm{AKI}$ setelah operasi kardiak. Pada tahun 2014 food and drug administrator (FDA) menyetujui penggunaan kombinasi konsentrasi tissue inhibitor of metalloproteinase 2 (TIMP-2) and insulin like growth factor binding protein 7 (IGFBP7) urin untuk menentukan apakah pasien critical ill berisiko untuk berkembang menjadi AKI berat. ${ }^{12}$

Sel tubular yang mengalami injury akan mengekspresikan IGFBP7 dan TIMP-2 dalam sel tubular. IGFBP7 langsung meningkatkan ekspresi p53 dan p21 dan TIMP2 merangsang ekspresi p27. Efek ini dilakukan secara autokrin dan parakrin melalui reseptor IGFBP7 dan TIMP-2. Protein $\mathrm{P}$ pada gilirannya memblokir efek dari kompleks protein CDK (CyclD-Cdk4 dan siklus-Cdk2) pada siklus sel, sehingga menghasilkan G1 cell-cycle arrest untuk jangka waktu yang singkat untuk memisahkan dan menghindari sel lain dari kerusakan. ${ }^{12}$

Studi Wang et al (2014) mengevaluasi diagnosis dini, stratifikasi risiko, dan nilai prognostik neutrophil gelatinase-associated lipocalin (NGAL), matrix metalloproteinase-9 (MMP-9) dan tissue inhibitor of matrix metalloproteinases-1 (TIMP-1), dibandingkan dengan procalcitonin (PCT) dan skor Mortality in Emergency Department Sepsis (MEDS) 
pada pasien sepsis di ruang emergensi. Didapatkan rerata kadar NGAL dan TIMP-1 serum meningkat dengan beratnya sepsis. NGAL, MMP-9 dan TIMP-1 serum secara signifikan lebih tinggi pada pasien sepsis yang tidak bertahan dibandingkan yang bertahan dalam 28 hari rawatan. Kadar NGAL dan TIMP-1 serum berkorelasi positif dengan PCT dan skor MEDS pasien sepsis. Sehingga NGAL dan TIMP1 bisa digunakan untuk menilai stratifikasi risiko, diagnosis dini, prognostik sepsis di ruang emergensi. NGAL juga bisa dipakai sebagai biomarker prognostik pasien sepsis dengan $\mathrm{AKI}$ di ruang emergensi. ${ }^{13}$

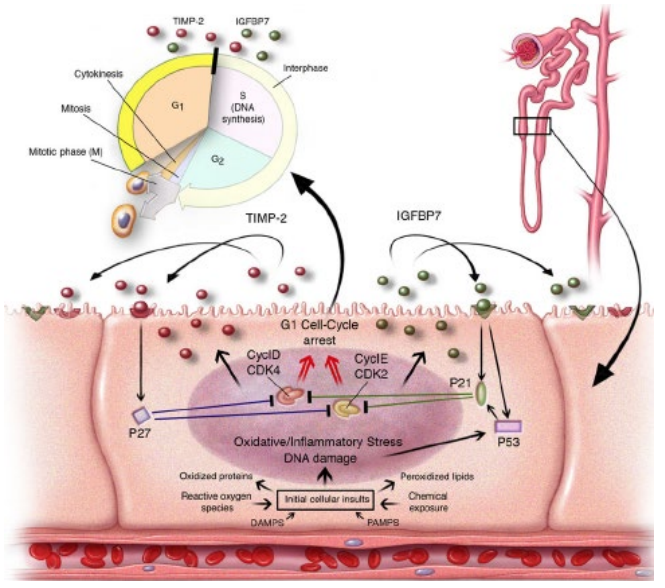

Gambar 3. Proses G1 Cell-Cycle arrest. ${ }^{13}$

Kashani et al (2013) menguji biomarker pada 340 pasien kritis yang berisiko untuk AKI, dimana IGFBP-7 dan TIMP-2 mengungguli penanda lain dari AKI termasuk NGAL urine / plasma, KIM-1 urin, interleukin-18 urin, cystatin $\mathrm{C}$, dan kreatinin serum untuk memprediksi AKI onset 12-36 jam setelah pengumpulan sampel. Perlu dicatat bahwa IGFBP7 dan TIMP-2 terlibat dengan fenomena G1 cell-cycle arrest yang merupakan fase sangat awal dari cedera sel. ${ }^{14}$

Untuk memandu penggunaan klinis dari dua penanda ini untuk penilaian risiko, Bihorac et al (2014) memilih cutoff dengan sensitivitas tinggi dengan menggunakan hasil dari studi sebelumnya yang mempelajari 420 pasien dewasa dengan sakit kritis dalam waktu 24 jam yang masuk ke unit perawatan intensif (ICU). Didapatkan tes nilai TIMP-2 dan IGFBP7 lebih besar dari 0,3 memiliki tujuh kali berisiko AKI (95\% Cl, 4-22) dibandingkan dengan nilai cut off di bawah 0,3 . Suatu analisis sekunder pada nilai cutoff
2,0 menunjukkan spesifisitas $95 \%$ dan sensitivitas $37 \% .{ }^{15}$

\section{Simpulan}

Sepsis merupakan salah satu penyebab acute kidney injury (AKI). Patofisiologi acute kidney injury (AKI) pada sepsis disebabkan oleh respon inflamasi, toxin dan perubahan hemodinamik glomerolus. Tingkat keparahan disfungsi ginjal bergantung dengan tingkat keparahan sepsis. Pemeriksaan biomarker bisa digunakan sebagai diagnostik dini acute kidney injury (AKI) akibat sepsis.

\section{Daftar Pustaka}

1. Dellinger RP, Levy MM, Rhodes A, Annane $D$, Gerlach H, Opal SM, et al. Surviving sepsis campaign: international guidelines for management of severe sepsis and septic shock: 2012. Crit Care Med. 2013; 41:580 637.

2. Angus DC, Linde-Zwirble WT, Lidicker J, Clermont G, Carcillo J, Pinsky MR. Epidemiology of severe sepsis in the United States: analysis of incidence, outcome, and associated costs of care. Crit Care Med 2001;29:1303-10.

3. Mandelbaum T, Scott DJ, Lee J, Mark RG, Malhotra A, Waikar SS, et al. Outcome of critically ill patients with acute kidney injury using the Acute Kidney Injury Network criteria. Crit Care Med. 2011; 39:2659-64.

4. Susantitaphong $P$, Cruz DN, Cerda J, Abulfaraj M, Alqahtani F, Koulouridis I, et al. World incidence of AKI: a meta-analysis. Clin J Am Soc Nephrol. 2013; 8:1482-93.

5. Kane-Gill SL, Sileanu FE, Murugan R, Trietley GS, Handler SM, Kellum JA, et al. Risk factors for acute kidney injury in older adults with critical illness: a retrospective cohort study. Am J Kidney Dis. 2015; 65:860-9.

6. Roesli, RMA. Diagnosis dan Pengelolaan Gangguan Ginjal Akut. Pusat Penerbitan IImiah Bagian IImu Penyakit Dalam FK UNPAD/RS dr. Hasan Sadikin, Bandung; 2008.hlm.41-66.

7. Hsu CY, Ordonez JD, Chertow GM, Fan D, McCulloch CE, Go AS et al. The risk of acute renal failure in patients with chronic kidney disease. Kidney Int. 2010; 74:101-7.

8. Lopes J, Jorge S, Resina C, Santos C, Pereira I, Neves J, Antunes F, et al. Acute kidney injury in patients with sepsis: a contemporary analysis. International Journal of Infectious Diseases. 2009;13: 176-181

9. Prowle JR, and Bellomo R. Sepsisassociated acute kidney injury: 
macrohemodynamic and microhemodynamic alterations in the renal circulation. Semin Nephrol. 2015; 35:64-74.

10. Parikh AG, Moledina DG, Coca SG, Philbrook TS and Garg AX. Application of new acute kidney injury biomarkers in human randomized controlled trials. Kidney International. 2016 ;89: 1372-1379

11. Hidayat $H$, Ida P, Rubin SG, dan Coriejati R. Uji Validitas Neutrophil Gelatinase Associated Lipocalin sebagai Penanda Diagnosis Gangguan Ginjal Akut pada Sepsis. MKB. 2012;44(2):1-6

12. Kellum JA and Chawla LS. Cell-cycle arrest and acute kidney injury: the light and the dark sides. Nephrol Dial Transplant. 2016; 31: 16-22

13. Wang $M$, Zhang Q, Zhao Z, Dong $G$ and Li C. Diagnostic and prognostic value of neutrophil gelatinase-associated lipocalin, matrix metalloproteinase-9, and tissue inhibitor of matrix metalloproteinases-1 for sepsis in the Emergency Department: an observational study. Critical Care. 2014; 18:634.

14. Kashani K, Al-Khafaji A, Ardiles T, Artigas A, Bagshaw SM, et al. Discovery and validation of cell cycle arrest biomarkers in human acute kidney injury. Critical Care. 2013; 17:25.

15. Bihorac A, Chawla LS, Shaw AD, Al-Khafaji A, Davison DL, et al. Validation of Cell-Cycle Arrest Biomarkers for Acute Kidney Injury Using Clinical Adjudication. Am J Respir Crit Care Med 2014;189: 932-939. 